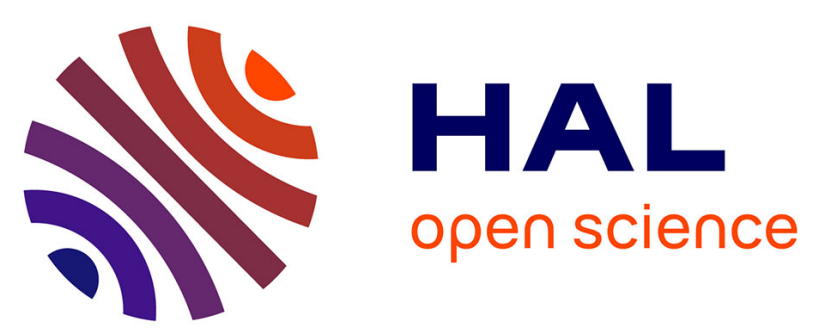

\title{
Non-Destructive Portable Analytical Techniques for Carbon In-Situ Screening Before Sampling for Dating Prehistoric Rock Paintings
}

Lucile Beck, Dominique Genty, Sophia Lahlil, Matthieu Lebon, Florian

Téreygeol, Colette Vignaud, Ina Reiche, Elsa Lambert, Hélène Valladas, Evelyne Kaltnecker, et al.

\section{To cite this version:}

Lucile Beck, Dominique Genty, Sophia Lahlil, Matthieu Lebon, Florian Téreygeol, et al.. NonDestructive Portable Analytical Techniques for Carbon In-Situ Screening Before Sampling for Dating Prehistoric Rock Paintings. Radiocarbon, 2013, 55 (3-4), pp.436 - 444. 10.2458/azu_js_rc.55.16248 . hal-02456519

\author{
HAL Id: hal-02456519 \\ https://hal.science/hal-02456519
}

Submitted on 2 Nov 2020

HAL is a multi-disciplinary open access archive for the deposit and dissemination of scientific research documents, whether they are published or not. The documents may come from teaching and research institutions in France or abroad, or from public or private research centers.
L'archive ouverte pluridisciplinaire HAL, est destinée au dépôt et à la diffusion de documents scientifiques de niveau recherche, publiés ou non, émanant des établissements d'enseignement et de recherche français ou étrangers, des laboratoires publics ou privés. 


\title{
NON-DESTRUCTIVE PORTABLE ANALYTICAL TECHNIQUES FOR CARBON IN SITU SCREENING BEFORE SAMPLING FOR DATING PREHISTORIC ROCK PAINTINGS
}

\author{
Lucile Beck ${ }^{1,2} \bullet$ Dominique Genty ${ }^{3}$ Sophia Lahlil ${ }^{2}$ Matthieu Lebon ${ }^{2,4} \bullet$ Florian Tereygeol $^{5}$. \\ Colette Vignaud ${ }^{2}$ Ina Reiche ${ }^{2}$ Elsa Lambert ${ }^{2}$ Hélène Valladas $^{3}$ • Evelyne Kaltnecker ${ }^{3}$. \\ Frédéric Plassard ${ }^{6}$ Michel Menu $^{2} \bullet$ Patrick Paillet $^{4}$
}

\begin{abstract}
Direct dating of prehistoric paintings is playing a major role in Paleolithic art studies. Very few figures can be directly dated since the necessary condition is that they contain organic carbon-based material. Thus, it is very important to check the presence of organic carbon-based material in situ before sampling in order to protect the visual integrity of the paintings or drawings. We have tested and compared 3 different portable analytical systems that can be used in cave environments for detecting carbon in prehistoric paintings: (1) a very compact X-ray fluorescence (XRF) system in Villars Cave (Dordogne, France); (2) a portable micro-Raman spectrometer in Rouffignac Cave (Dordogne, France); and (3) an infrared reflectography camera in both caves. These techniques have been chosen for their non-destructiveness: no sample has to be taken from the rock surface and no contact is made between the probes and the paintings or drawings. The analyses have shown that all the animal figures have been drawn with manganese oxides and cannot be directly dated by radiocarbon. However, carbon has been detected in several spots such as black dots and lines and torch marks. ${ }^{14} \mathrm{C}$ results were obtained from 5 torch marks selected in Villars Cave, with ages between 17.1-18.0 ka cal BP. Three methods were used to identify carbon in black pigments or to confirm the presence of torch marks by carbon detection. Thanks to these new analytical developments, it will be now possible to select more accurately the samples to be taken for ${ }^{14} \mathrm{C}$ dating prehistoric paintings and drawings.
\end{abstract}

\section{INTRODUCTION}

Direct dating of prehistoric paintings is playing a major role in Paleolithic art studies (Valladas et al. 1992, 2001). However, very few painting can be directly dated since the necessary condition is that they contain organic carbon-based material. Furthermore, in order to protect the visual integrity of the paintings or drawings, sampling must be accurately undertaken and limited. For those reasons, we propose to carry out in situ non-destructive chemical analysis to check for the presence of organic carbon-based material in pigment before sampling.

The first chemical analysis of prehistoric pigments began in the early 20th century with the discovery of prehistoric art (Moissan 1902). Advancements in the 1990s (Clottes et al. 1990; Menu et al. 1993) were mainly concerned with the study of the chaîne opératoire conducted by artists for the production of Paleolithic paintings and drawings (Menu and Walter 1992; Baffier et al. 1999; Menu and Vignaud 2006; Chalmin et al. 2008). More recently, an innovative approach without sampling has been developed for in situ characterization of paintings and drawings by directly analyzing the pigment material at the surface of the cave or shelter walls (de Sanoit et al. 2005; Tournié et al. 2010; Beck et al. 2012; Lahlil et al. 2012; Olivares et al. 2013). This approach, initially developed to determine the nature of pigments, can also be used to screen in situ the presence of organic carbon-based material in order to select suitable samples for radiocarbon dating.

${ }^{1}$ CEA, DEN, Service de Recherches de Métallurgie Physique, Laboratoire JANNUS, 91191 Gif-sur-Yvette, France. Corresponding author. Email: lucile.beck@cea.fr.

${ }^{2}$ C2RMF - UMR171 CNRS, Centre de Recherche et de Restauration des Musées de France, Palais du Louvre, Porte des Lions, 14 quai François Mitterrand, 75001 Paris, France.

${ }^{3}$ LSCE, UMR CEA/CNRS 8212, L’Orme des Merisiers CEA Saclay, 91191 Gif-sur-Yvette Cedex, France.

${ }^{4}$ Muséum National d’Histoire Naturelle, Département de Préhistoire, UMR 7194, 1 rue René Panhard, 75013 Paris, France.

${ }^{5}$ LAPA SIS2M UMR 3299 CEA-Saclay, 91191 Gif-sur-Yvette Cedex, France.

${ }^{6}$ S.A.R.L. Grotte de Rouffignac, 24580 Rouffignac-Saint-Cernin, France and Université de Bordeaux, PACEA, UMR 5199, 33400 Talence Cedex, France.

(C) 2013 by the Arizona Board of Regents on behalf of the University of Arizona Proceedings of the 21 st International Radiocarbon Conference edited by A J T Jull \& C Hatté RADIOCARBON, Vol 55, Nr 2-3, 2013, p 436-444 


\section{Beck et al.}

In the framework of this study, we have tested and compared 3 different portable analytical systems for carbon detection in figures or in black dots covering the walls of 2 prehistoric caves. The first system, a very compact X-ray fluorescence (XRF) system, has been used in Villars Cave (Dordogne, France). The second system is a portable micro-Raman spectrometer used in Rouffignac Cave (Dordogne, France). Tests of infrared reflectography have also been conducted in both caves. This article will present the capacities and performances of the devices in the cave environment. Based on these first measurements, samples from Villars Cave have been selected and taken from 5 torch marks for ${ }^{14} \mathrm{C}$ dating.

\section{METHODS AND RESULTS}

In recent years, significant advances have been made in the development of mobile systems. These use different sources of radiation (X-ray, infrared, visible light laser) that can probe fragile and valuable materials without touching them. Thanks to such analytical systems, it is now possible to study without sampling a large number of paintings and drawings in shelters or in prehistoric caves. Two devices specifically developed and used for museums (Raman spectroscopy and IR reflectography) and a commercial X-ray fluorescence (XRF) device are presented in this study.

\section{X-Ray Fluorescence Analysis in Villars Cave}

The device used in this study is a commercial XRF elemental analyzer (Niton XL3). The system is a single unit, hand-held and battery-powered (Figure 1). It is equipped with a 50-kV miniaturized Xray tube combined with an X-ray detector. It can detect chemical elements heavier than nickel (Z > 28 ) in a very short time (within $1 \mathrm{~min}$ ) and without contact with the wall. Therefore, we can easily measure the content of manganese and iron, the major elements of prehistoric pigments, by detecting the X-ray lines at 5.9 and $6.4 \mathrm{keV}$, respectively. Carbon is not detected directly, but its presence can be inferred from the absence of the above elements ( $\mathrm{Mn}$ and $\mathrm{Fe}$ ).

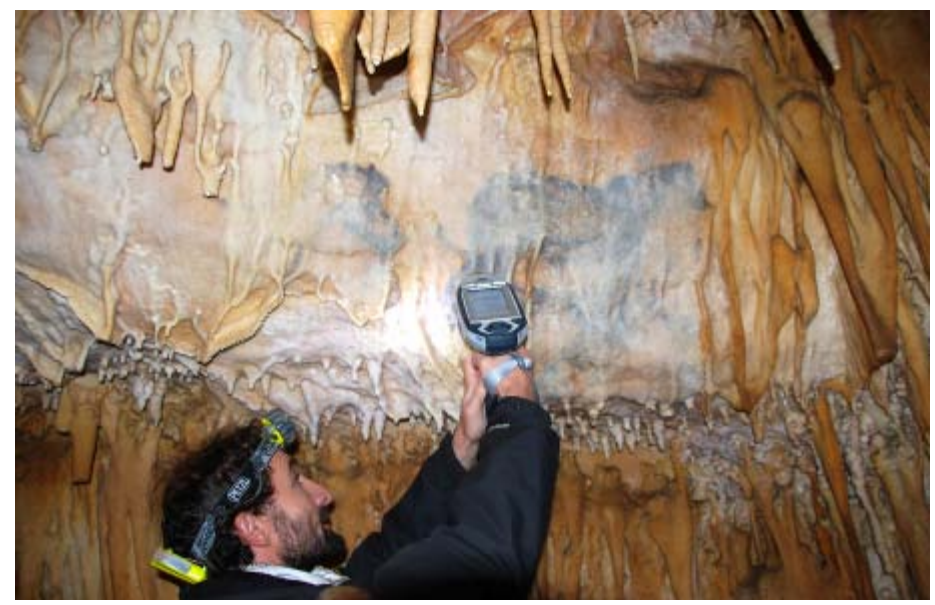

Figure 1 XRF measurement in Villars Cave (Dordogne, France) on the horse called Le petit cheval bleu in the Salle des Peintures (Painting Room).

Villars Cave is located in Dordogne, SW France. The cave is $\sim 600 \mathrm{~m}$ long and consists of several rooms connected by passageways. Around 30 drawings (horse, bison, ibex, etc.) and 30 sets of dots or lines have been discovered (Delluc and Delluc 1974). Most are made of black pigments and are stylistically attributed to the Magdalenian period. 


\section{Carbon Screening for Dating Prehistoric Rock Paintings}

A total of 22 XRF analyzes were performed on drawings, dots, and lines. Twelve results reveal the presence of manganese oxide for all the animal figures and for a few lines. The 10 other dark spots are made with carbon, probably originating from charcoal. One of these corresponds to a long line known as the Coulée de la Découverte, which is located in the Salle des Cierges (Candle Room). The others correspond to stains probably produced by torches. Among them, 5 locations were selected for ${ }^{14} \mathrm{C}$ dating: 2 dots on 2 different sets in the Recoin du Balcon; 2 other dots at the Carrefour (intersection between 2 galleries); and finally a black hidden dot near the narrow passage giving access to the Salle des Peintures (Painting Room).

Dating of these samples was performed at the ${ }^{14} \mathrm{C}$ laboratory of CEA Saclay, France. Pretreatment (chemical to oxidation in $\mathrm{CO}_{2}$ ) of the Villars samples was done at the LSCE lab (Gif-sur-Yvette, France). Fragments of charcoal taken from dark spots of the cave walls have undergone a series of acid/alkali/acid treatments $\left(90^{\circ} \mathrm{C}\right.$ for $60 \mathrm{~min}$ in the case of the largest samples and at a lower temperature for the others) for extracting carbonates and humic acids. The purified charcoal was then placed in a quartz tube with copper oxide and silver wire. This tube was sealed under vacuum and heated at $835^{\circ} \mathrm{C}$ for $5 \mathrm{hr}$. The $\mathrm{CO}_{2}$ obtained was then reduced to graphite on iron filings and pressed into an aluminum capsule for measurement with the ARTEMIS accelerator (UMS 2572, Saclay, France) by counting the number of $\mathrm{C}$ isotopes $\left({ }^{12} \mathrm{C},{ }^{13} \mathrm{C},{ }^{14} \mathrm{C}\right)$. The results are presented in Figure 2 and discussed below.

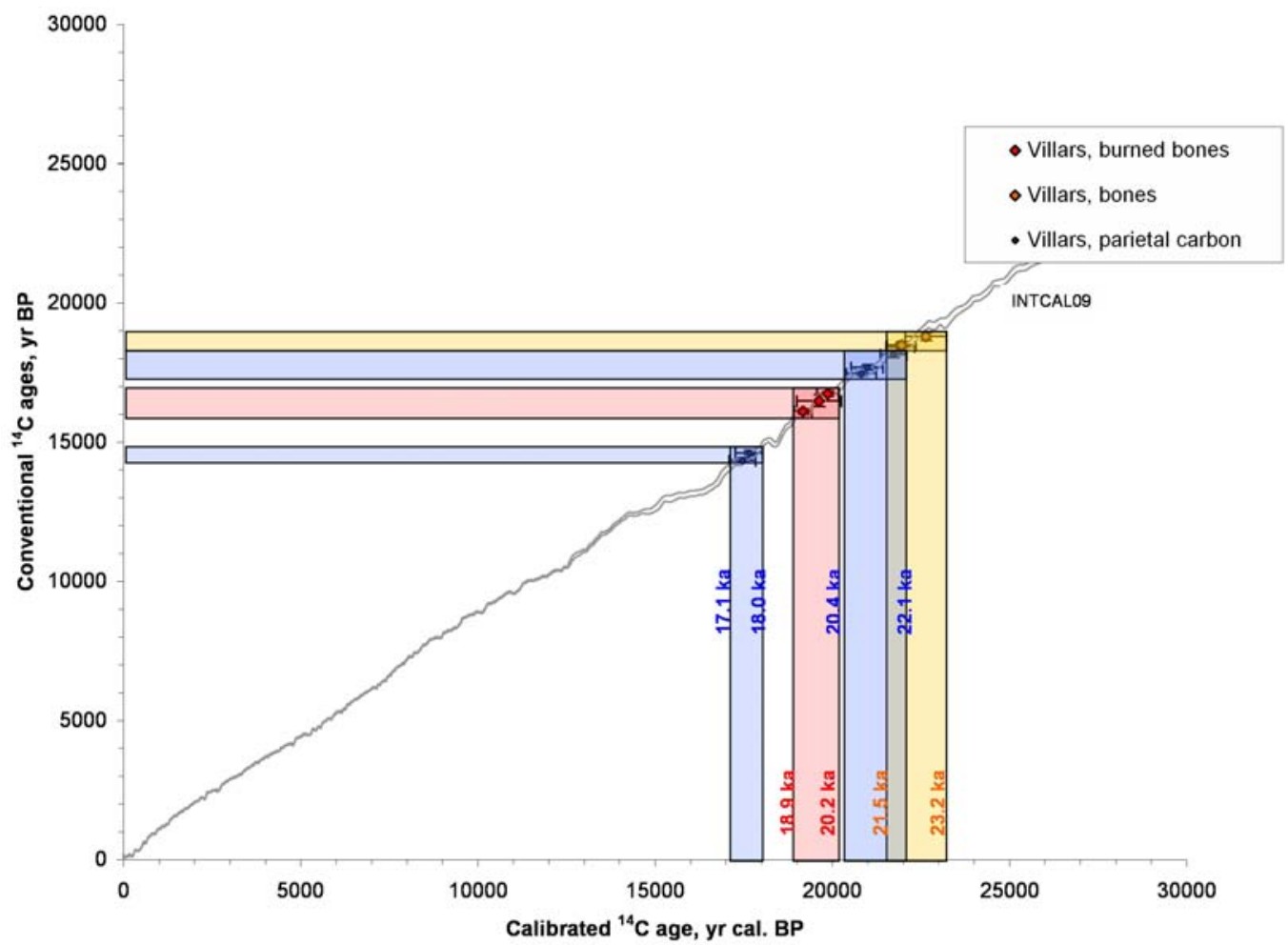

Figure $2{ }^{14} \mathrm{C}$ ages of samples collected in Villars Cave (Dordogne, France) plotted against the IntCal09 calibration curve

The 2 areas of torch marks of the Recoin du Balcon are dated to 20.4-21.25 and 21.36-22.11 cal ka BP (Figure 2). The age of the torch mark recently discovered at the narrow passage is similar to the 


\section{Beck et al.}

first of the 2 previous marks: 20.5-21.43 cal ka BP. The assigned age of these marks corresponds to the limit of the Ancient Magdalenian period. These results provide evidence that prehistoric men proceeded at least until the area of the Balcon about $30 \mathrm{~m}$ away from the Carrefour area, a place where we did not expect their passage. In turn, both results in the Carrefour are significantly younger: 17.1-17.84 and 17.27-18.05 cal ka BP, suggesting a frequentation of the cave 3 ka later from the previous one (Genty et al., in press).

These results are the first dates obtained on torch marks found on the walls of Villars Cave. Up to now, and besides the age estimation based on the style of the paintings, only $1{ }^{14} \mathrm{C}$ date had been carried out on a fragment of burnt bone (19.0-20.5 cal ka BP: D Genty, unpublished data). Thus, the dates obtained on torch marks, which range from 20.4 and $22.1 \mathrm{cal}$ ka BP, confirm this period of occupation (Figure 2). All the samples taken from this cave, selected after the screening survey by XRF spectrometry, give Paleolithic ages consistent with their stylistic analysis.

\section{Raman Micro-Spectroscopy in Rouffignac Cave}

Raman spectroscopy is a technique used to analyze chemical bonds and the symmetry of molecules. This technique is useful for identifying mineralogical phases in cultural heritage artifacts and pigments (Ricciardi et al. 2009; Tournié et al. 2010). In the case of prehistoric art, micro-Raman analyses have been undertaken on samples (Hernanz et al. 2006, 2008; Ospitali et al. 2006), but a recent study has shown that Raman analyses could also be performed in situ, on the red and white paintings of the San rockshelter dating from 3000 BP (Tournié et al. 2010).

The Raman spectral features of graphite and related materials are well defined and correspond to 2 intense bands at 1390 and $1590 \mathrm{~cm}^{-1}$ (Tomasini et al. 2012). Raman spectroscopy is a very sensitive technique that can identify carbon-based material within minutes without any damages for the drawings studied. The quantification of the pigment amount is, however, not possible.

In this study, micro-Raman analyses were performed using a commercial micro-Raman spectrometer (HE532-HORIBA Scientific, Jobin Yvon Technology) in Rouffignac Cave (Dordogne, France). It is equipped with a charge-coupled device (CCD) multichannel matrix detector (1024 × 256 pixels) operating at $-70{ }^{\circ} \mathrm{C}$. The source is an Nd:YAG laser operating at $532 \mathrm{~nm}$, providing a maximum power of $\sim 100 \mathrm{~mW}$. To avoid sample alteration (particularly dehydration), Raman spectra were recorded using a low excitation power on the drawings using the electronic power control of the laser. The 5-m-long optical fibers allow separating the SuperHead from the bulkier spectrometer. A $50 \times$ Nikon long-working distance lens ( $\sim 15 \mathrm{~mm}$ from the sample) was used to avoid any contact with the area analyzed (Figure 3). The duration of 1 Raman analysis is a few minutes.

Rouffignac Cave is one of the major sites of Paleolithic cave art. It has been widely studied by archaeologists and scientists to answer authentication and conservation issues. Understanding of the origin and technique of the drawings and engravings present on the walls is of main interest (Barrière 1982; Plassard 1999). Some 240 drawn or engraved figures of animals have been identified. The predominance of mammoths as well as a number of well-organized panels arranged as friezes are some of the remarkable elements of this cave. Drawings are always made of black pigment.

Although no direct dating has been carried out, mainly due to the lack of identified charcoal-based figures, the style of this cave is generally connected to the Magdalenian period. Consequently, one of the objectives of this screening campaign was to find some carbon-based figures in order to confirm the stylistic approach. 


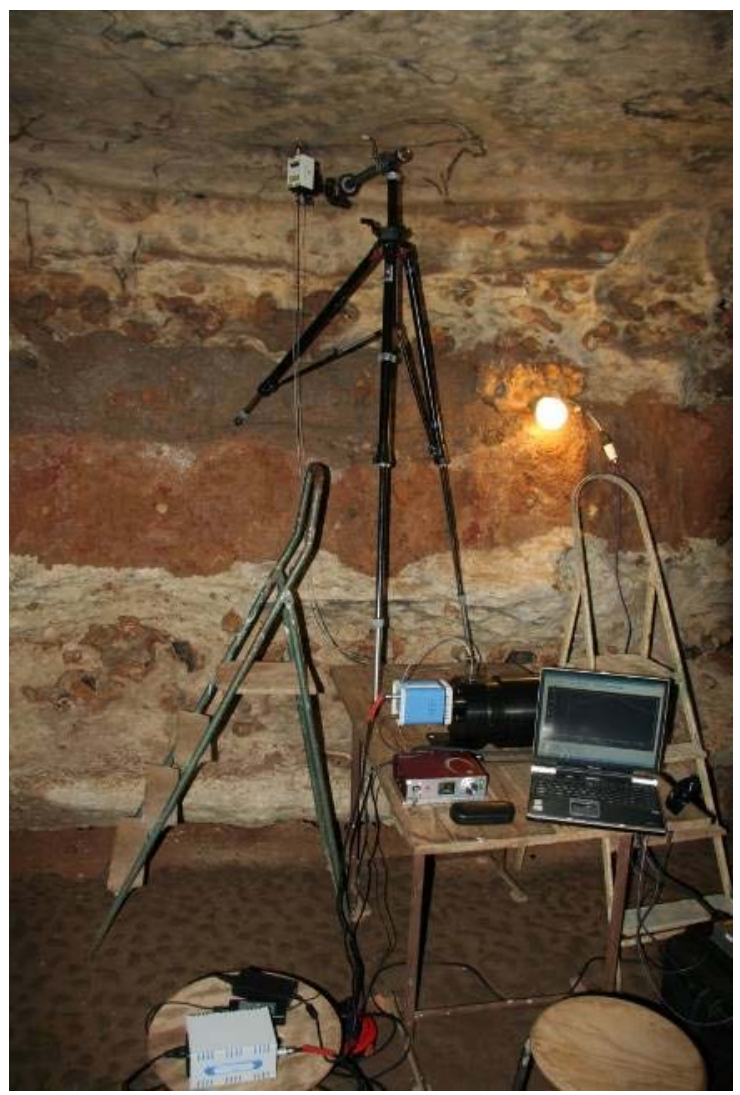

Figure 3 Raman spectrometer in Rouffignac Cave (Dordogne, France), Great Ceiling (Grand Plafond).

Two main locations have been selected to perform the analyses: the Great Ceiling (Grand Plafond) and the Henri Breuil Gallery. The Great Ceiling gathered 65 figures without any striking global organization, whereas the Henri Breuil Gallery with its "ten mammoth frieze" and "rhino frieze" is well structured. Another location presenting 2 "faced mammoths" was also studied. Located a few hundred meters from the Henri Breuil Gallery and the Great Ceiling, these 2 drawings are isolated from the rest of the cave. A total of 10 figures were studied: in the Henri Breuil Gallery, 4 of the 10 mammoths of the frieze forming a stylistically homogeneous group and 1 rhino of the "three rhino frieze"; 3 drawings of the Great Ceiling; and the 2 isolated "faced mammoths."

The results of previous studies using different methods of spectrometry, XRF, X-ray diffraction, Raman analyses (de Sanoit et al. 2005; Beck et al. 2012; Lahlil et al. 2012) have confirmed that the figures of Rouffignac Cave are composed of manganese oxides as pigments. However, we have also observed carbon-containing areas using micro-Raman spectroscopy: the line considered as modern covering the head of the mammoth (\#66) located in the Great Ceiling; b) small carbon particles on the mammoth (\#180) of the 2 isolated "faced mammoths"; and c) a carotenoid-type organic carbon on the mammoth frieze and the rhino frieze.

The Raman spectra of the black line crossing the front of mammoth \#66 clearly show that the material employed for the line is carbon based (Figure 4a). The 2 broad bands at 1390 and $1590 \mathrm{~cm}^{-1}$ are characteristic of D and G bands of amorphous carbon (Tomasini et al. 2012). No bands from phosphates have been observed, which excludes the use of bone black or ivory black. The spectra 


\section{Beck et al.}

obtained are in good agreement with the use of charcoal of vegetal origin or soot. Since the charcoal or soot line overlays the head of the mammoth, it seems to be have been added in more recent times. Sufficient carbon is present so that this result could be confirmed or not by ${ }^{14} \mathrm{C}$ dating.

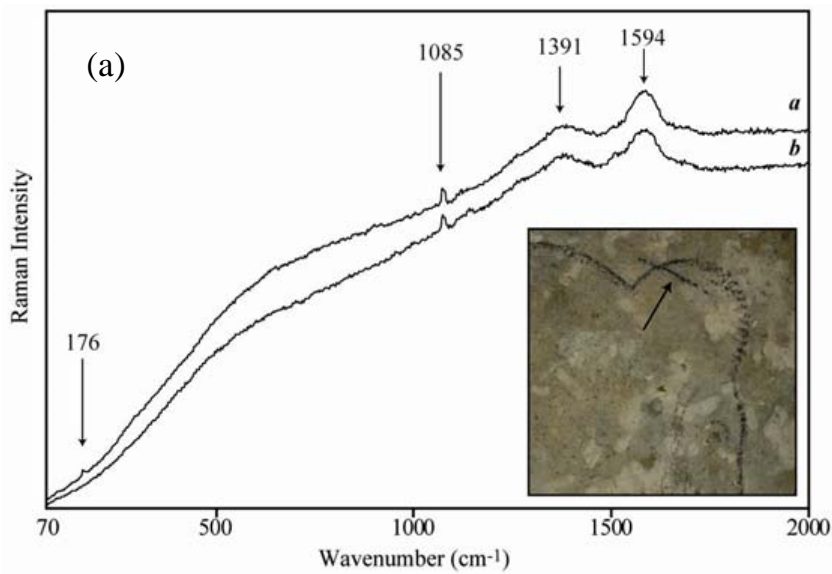

Figure 4 Raman spectra obtained from 2 figures of Rouffignac Cave (Dordogne, France): (a) Line crossing the head of mammoth \#66: The bands at 1391 and $1594 \mathrm{~cm}^{-1}$ are characteristic of the D and $\mathrm{G}$ bands of carbon; (b) Head of mammoth \#180: the 2 weak bands at $~ 580$ and $650 \mathrm{~cm}^{-1}$ are characteristic of manganese oxides. Two other broad bands are characteristic of carbon.

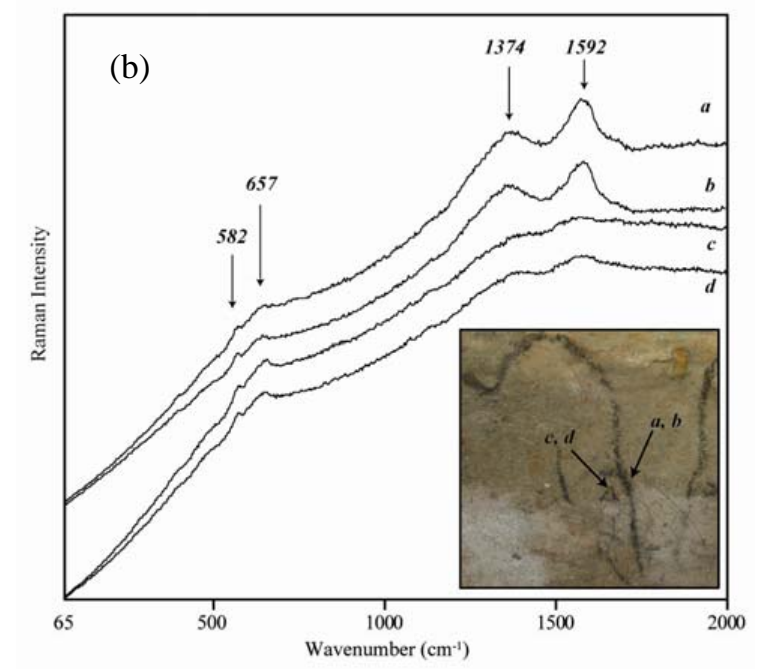

Raman spectra obtained at the forehead-eyebrow of mammoth \#180 exhibit 2 weak bands at 580 and $650 \mathrm{~cm}^{-1}$, which are characteristic of manganese oxides. Two other broad bands located at $\sim 1370$ and $1590 \mathrm{~cm}^{-1}$ are observed. They are characteristic of amorphous carbon such as charcoal (Figure 4b). Contrary to mammoth \#66 where amorphous carbon has been detected on a line transversal to the head, the detected carbon of mammoth $\# 180$ consists of small particles belonging to the mammoth drawing itself. The presence of amorphous carbon particles mixed with other pigments has already been found in red or black paintings from the Paleolithic (Ospitali et al. 2006; Chalmin et al. 2008). It could result from the soot from lamps used to illuminate the walls, or organic matter contained in the original pigment, or to a later redrawing. Since the presence of carbon has been detected very locally and in very low amounts, it seems difficult to take any sample for ${ }^{14} \mathrm{C}$ dating. 
For the mammoth and rhino friezes, manganese oxides have been detected at 580 and $650 \mathrm{~cm}^{-1}$. In addition, 2 weak bands at 1140 and $1510 \mathrm{~cm}^{-1}$ have been recorded in very local areas. These features are typical of organic material with a long carotenoid chain ( $\mathrm{C}=\mathrm{C}$ and $\mathrm{C}-\mathrm{C}$ stretching modes). These substances are widespread in nature and have been already found in several prehistoric sites (Hernanz et al. 2008; Tournié et al. 2010). They can come from red pigments of biological origin (e.g. seashells) or from photosynthetic bacteria. In both cases, the amount of these compounds is very low, and due to their uncertain origin, they do not seem suitable for ${ }^{14} \mathrm{C}$ dating.

These examples have shown the efficiency of micro-Raman spectroscopy for the detection of carbon in prehistoric drawings and paintings. However, the studies in Rouffignac Cave failed to highlight figures entirely performed with charcoal pigment. Thus, no sampling has been done on these figures for dating.

\section{Infrared Reflectography in the Rouffignac and Villars Caves}

Infrared reflectography (IR) is used in museums to decrypt painting techniques revealing artist corrections and redrawing. Indeed, infrared radiation goes through most of the paint layers except the black lines that are revealed by contrast (van Asperen de Boer 1968). This study presented an opportunity to conduct the first test of an infrared camera in a cave environment. In the Rouffignac and Villars caves, we used an infrared imaging system specially designed for art conservators (OSIRISOpus Instruments) (Figure 5a). This camera provides high-resolution and high-speed images of black drawings. Shots were made in the Painting Room (Salle des Peintures) of Villars Cave and on the Great Ceiling (Grand Plafond) of Rouffignac Cave. As an example, a figure representing the mammoth \#66 covered by an assumed modern line composed of carbon (confirmed by Raman analyses) is presented in Figure 5b (visible light) and in Figure 5c (IR). While the mammoth drawing and the transversal line both appear dark black in visible light, they present different gray levels in IR photographs. It is thus possible to distinguish the 2 different materials used in this figure to make the black lines: with IR, manganese oxide, which constitutes the animal figure, appears black while the charcoal-based line partially disappears. This first test shows that it is possible by this nondestructive photographic technique to isolate figures or lines made with carbon.

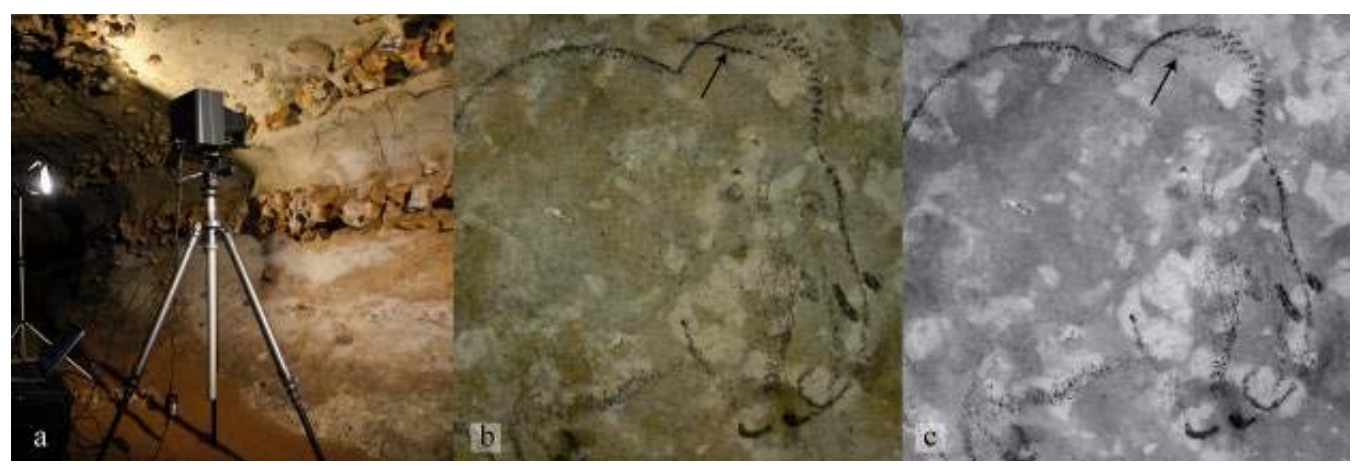

Figure 5 (a) Infrared camera in Rouffignac Cave; photographs (b) with visible light and (c) with infrared of mammoth \#66 on the Grand Plafond.

\section{CONCLUSION}

These various portable systems have successfully demonstrated their capabilities to identify carbon in pigments. The carbon screening methods can be applied in situ, in various types of environments, even in sites of high humidity such as prehistoric caves. Through the study of the Villars and Rouf- 


\section{Beck et al.}

fignac caves, we have demonstrated the possibility of implementing portable instruments for the detection of organic carbon in prehistoric drawings or paintings and for the identification of torch marks. The results are promising since the methods have provided valuable information on the composition of pigments and black marks without sampling.

Although X-ray fluorescence (XRF) is not able to detect carbon directly, this portable elemental analyzer has the advantage of being easy to use and battery-powered. This is the most compact device that we have tested in cave conditions thanks to its batteries and its short acquisition time. Without obtaining a detailed characterization of the material, this type of analysis performed with a commercial detector is sufficient to screen for the presence of black pigments that do not contain manganese or iron and that are therefore likely to be carbon-based.

Micro-Raman spectroscopy has proven particularly effective and sensitive for the direct detection of organic matter, including carbon. Despite a bit bulky setup, flexible optical fibers allow easy access to the irregular cave walls. The use of this method for the selection of charcoal pigment is very efficient. Infrared reflectography is also relatively easy to apply to prehistoric paintings and drawings, but further tests are necessary to improve the carbon/manganese discrimination.

In conclusion, thanks to the development of new portable and non-destructive analytical instruments, it is now possible to select suitable samples for ${ }^{14} \mathrm{C}$ dating in situ in the cave. After determination of the chemical composition, the samples can be taken from the site and their number limited by selecting the most appropriate figure or mark. This procedure is very useful for the preservation of the visual integrity of the paintings or drawings and more generally for the rock art preservation. These tools should prove useful in future ${ }^{14} \mathrm{C}$ dating of prehistoric paintings and drawings.

\section{ACKNOWLEDGMENTS}

This study was partially funded by the French Research Agency (ANR) in the framework of the MADAPCA project. We warmly thank the cave owners that allowed us to do these analyses: the Versaveaud family for Villars Cave and the Plassard family for Rouffignac Cave. We also would like to thank J-Cl Dran for his assistance during the manuscript preparation.

\section{REFERENCES}

Baffier D, Girard M, Menu M, Vignaud C. 1999. Color at the Grande Grotte, Arcy-Sur-Cure (Yonne, France). L'Anthropologie 103:1-21.

Barrière Cl. 1982. L'art pariétal de Rouffignac. Paris: Picard. 208 p.

Beck L, Rousselière H, Castaing J, Duran A, Lebon M, Lahlil S, Plassard F. 2012. Analyse in situ des dessins préhistoriques de la grotte de Rouffignac par fluorescence X et diffraction X portable. ArchéoSciences 36: 139-52.

Chalmin E, Sansot E, Orial G, Bousta F, Reiche I. 2008. Microanalysis and synthesis of calcite. Growth mechanisms on prehistoric paintings in the Large Cave, Arcy-sur-Cure (Yonne, France). X-Ray Spectrometry 37(4):424-34.

Clottes J, Menu M, Walter P. 1990. La préparation des peintures magdaléniennes des cavernes ariégeoises. Bulletin de la Société Préhistorique Française 87: $170-92$.
Delluc B, Delluc G. 1974. La grotte ornée de Villars. Gallia Préhistoire 17:1-67.

de Sanoit J, Chambellan D, Plassard F. 2005. Caractérisation in situ du pigment noir de quelques œuvres pariétales de la Grotte de Rouffignac à l'aide d'un système portable d'analyse par fluorescence X (XRF). ArchéoSciences 29:61-98.

Genty D, Valladas H, Beck L, Téreygeol F, Delluc B, Delluc G, Regnier E, Baritaud T, Hellstrom J, Blamart DC, Kaltnecker E, Moreau C, Dumoulin JP. In press. La grotte de Villars: données chronologiques de l'occupation humaine et contexte environnemental. PALEO.

Hernanz A, Gavira-Vallejo JM, Ruiz-López JF. 2006. Introduction to Raman microscopy of prehistoric rock paintings from the Sierra de las Cuerdas, Cuenca, Spain. Journal of Raman Spectroscopy 37(10):105462.

Hernanz A, Gavira-Vallejo JM, Ruiz-López JF, Edwards 


\section{Carbon Screening for Dating Prehistoric Rock Paintings}

HGM. 2008. A comprehensive micro-Raman spectroscopic study of prehistoric rock paintings from the Sierra de las Cuerdas, Cuenca, Spain. Journal of Raman Spectroscopy 39(8):972-84.

Lahlil S, Lebon M, Beck L, Rousselière H, Vignaud C, Reiche I, Menu M, Paillet P, Plassard F. 2012. The first in situ micro-Raman spectroscopic analysis of prehistoric cave art of Rouffignac St-Cernin, France. Journal of Raman Spectroscopy 43(11):1637-43.

Menu M, Vignaud C. 2006. L'analyse des techniques des peintres de Lascaux. Monumental. p 98-103.

Menu M, Walter P. 1992. Prehistoric cave painting PIXE analysis for the identification of paint "pots." Nuclear Instruments and Methods in Physics Research B 64(14):547-52.

Menu M, Walter P, Vigears D, Clottes J. 1993. Façons de peindre au Magdalénien: Niaux (Ariège). Bulletin de la Société Préhistorique Française 90:426-32.

Moissan H. 1902. Sur les matière colorantes de figures de la grotte de Font-de-Gaume. Compte rendus de l'Académie des sciences 134:1536-40.

Olivares M, Castro K, Corchón MS, Gárate D, Murelaga X, Sarmiento A, Etxebarria N. 2013. Non-invasive portable instrumentation to study Palaeolithic rock paintings: the case of La Peña Cave in San Roman de Candamo (Asturias, Spain). Journal of Archaeological Science 40(2):1354-60.

Ospitali F, Smith DC, Lorblanchet M. 2006. Preliminary investigations by Raman microscopy of prehistoric pigments in the wall-painted cave at Roucadour, Quercy, France. Journal of Raman Spectroscopy 37(10):1063-71.

Plassard J. 1999. Rouffignac, le sanctuaire des mammouths. Paris: Le seuil. 96 p.

Reimer PJ, Baillie MGL, Bard E, Bayliss A, Beck JW,
Blackwell PG, Bronk Ramsey C, Buck CE, Burr GS, Edwards RL, Friedrich M, Grootes PM, Guilderson TP, Hajdas I, Heaton T, Hogg AG, Hughen KA, Kaiser KF, Kromer B, McCormac FG, Manning SW, Reimer RW, Richards DA, Southon JR, Talamo S, Turney CSM, van der Plicht J, Weyhenmeyer CE. 2009. IntCal09 and Marine09 radiocarbon age calibration curves, 0-50,000 years cal BP. Radiocarbon 51(4): 1111-50.

Ricciardi P, Colomban P, Tournié A, Milande V. 2009. Nondestructive on-site identification of ancient glasses: genuine artefacts, embellished pieces or forgeries? Journal of Raman Spectroscopy 40(6):604-17.

Tomasini EP, Halac EB, Reinoso M, Di Liscia EJ, Maier MS. 2012. Micro-Raman spectroscopy of carbonbased black pigments. Journal of Raman Spectroscopy 43(11):1671-5.

Tournié A, Prinsloo LC, Paris C, Colomban P, Smith B. 2010. The first in situ Raman spectroscopic study of San rock art in South Africa: procedures and preliminary results. Journal of Raman Spectroscopy 42(3): 399-406.

Valladas H, Cachier H, Maurice P, Bernaldo De Quiros F, Clottes J, Cabrera Valdes V, Uzquiano P, Arnold M. 1992. Direct radiocarbon dates for prehistoric paintings at the Altamira, El Castillo and Niaux caves. $\mathrm{Na}$ ture 357(6373):68-70.

Valladas V, Tisnérat-Laborde N, Cachier H, Arnold M, Bernaldo de Quirós F, Cabrera-Valdés V, Clottes J, Courtin J, Fortea-Pérez J J, Gonzáles-Sainz C, MoureRomanillo A. 2001. Radiocarbon AMS dates for Paleolithic cave paintings. Radiocarbon 43(2B):977-86.

van Asperen de Boer JRJ. 1968. Infrared reflectography: a method for the examination of paintings. Applied Optics 7(9):1711-4. 